\title{
Modulation of Keratinocyte Proliferation In Vitro by Endogenous Prostaglandin Synthesis
}

\author{
Alice P. Pentland and Philip Needleman \\ Departments of Dermatology and Pharmacology, Washington University School of Medicine, St. Louis, Missouri 63110
}

\begin{abstract}
To understand the relationship between the proliferation of epidermis and its arachidonic acid metabolism, we studied human keratinocytes grown in vitro at confluent or nonconfluent densities. Keratinocyte cultures incubated with $\left[{ }^{14} \mathrm{C}\right.$ arachidonic acid synthesized prostaglandin (PG)E $\mathbf{P G D}_{2}, \mathbf{P G F}_{2 \alpha}$, and small quantities of 6-keto- $F_{1 \alpha}$. Nonconfluent cultures, however, synthesized fourfold more PGE $_{2}$ than did confluent cultures. When proliferation was studied using $\left[{ }^{3} \mathbf{H}\right]$ thymidine incorporation into DNA, it was found that this increased synthesis of $\mathrm{PGE}_{2}$ was accompanied by a fourfold increase in the rate of proliferation. When $\mathrm{PGE}_{2}$ synthesis was inhibited by indomethacin, the rate of proliferation of nonconfluent cultures was decreased $40 \%$, while the rate of proliferation of confluent cultures was unchanged. Addition of $1 \mathrm{ng} / \mathrm{ml}$ of $\mathrm{PGE}_{2}$, but not $\mathbf{P G F}_{2 \alpha}, \mathbf{P G D}_{2}$, or a stable analog of $\mathbf{P G I}_{2}$ to the indomethacin-treated nonconfluent cultures restored the initial rate of proliferation. These results suggest that $\mathbf{P G E}_{2}$ is a growth-promoting autocoid for epidermis. The synthesis of PGE $_{2}$ by epidermis may be enhanced in wound healing and disease states where epidermal continuity is disrupted.
\end{abstract}

\section{Introduction}

The participation of prostaglandin (PG) ${ }^{1}$ synthesis in keratinocyte proliferation has been suggested in several ways. In hyperproliferation induced in mouse epidermis by $12-O$-tetradecanoylphorbol-13-acetate (TPA), there is an associated increase in endogenous synthesis of $\mathrm{PGE}_{2}$ (1). This TPA-induced hyperproliferation can be blocked by indomethacin and restored by topical application of $\operatorname{PGE}_{2}(2,3)$. It has also been shown that intradermal injection of $\mathrm{PGE}_{1}$ or $\mathrm{PGE}_{2}$ results in increased epidermal proliferation $(4,5)$. Similar increases in the rate of proliferation (6) have been shown in cultured keratinocytes after exogenous addition of $\mathrm{PGE}_{1}$. In addition, healing of partial thickness burns requires three times longer in essential fatty acid-

Portions of this work were presented at the Federation of American Societies for Experimental Biology meeting in Los Angeles, April 1985.

Address correspondence to Dr. Needleman, Department of Pharmacology, Washington University School of Medicine, 660 South Euclid Ave., St. Louis, MO 63110.

Received for publication 20 February 1985 and in revised form 26 August 1985.

1. Abbreviations used in this paper: EFAD, essential fatty acid deficient; $\left[{ }^{3} \mathrm{H}\right] \mathrm{Tdr}$, tritiated thymidine; PG, prostaglandin; TPA, 12-O-tetradecanoylphorbol-13-acetate.

J. Clin. Invest.

(c) The American Society for Clinical Investigation, Inc.

$0021-9738 / 86 / 01 / 0246 / 06 \$ 1.00$

Volume 77, January 1986, 246-251 deficient (EFAD) rats, which are devoid of fatty acid precursors for PG synthesis (7).

There is also conflicting evidence that shows that $\mathrm{PGE}_{2}$ inhibits epidermal proliferation. It has been shown that addition of $\mathrm{PGE}_{2}, \mathrm{PGE}_{1}, \mathrm{PGF}_{2 \alpha}$, and $\mathrm{PGF}_{1 \alpha}$ to the culture medium of human epidermal explants results in $35-87 \%$ inhibition of proliferation (8). In essential fatty acid-deficient rats, presumably with deficient epidermal synthesis of $\mathrm{PGE}_{2}$, the rate of epidermal proliferation is increased fivefold over control values (9). Topical application of $\mathrm{PGE}_{2}$ daily for 1 wk restores the slower, normal rate of proliferation (10).

The confusion in the results of these studies may be attributable to several factors: $(a)$ the wide variety of doses and types of prostaglandin selected for study, $(b)$ the varying intervals of treatment, $(c)$ the different animal models or culture conditions selected, and $(d)$ the failure to identify the intrinsic product profile of arachidonic acid metabolism in keratinocytes. To clarify the role of arachidonic acid metabolism in epidermal proliferation, we have done a series of experiments to determine the endogenous pattern of arachidonate metabolism in cultured human keratinocytes and studied the role of endogenously synthesized prostaglandins in keratinocyte proliferation.

\section{Methods}

Primary human keratinocyte cultures. Full-thickness skin from panniculectomies and breast reductions from healthy individuals was used. The basal cells from these biopsy specimens were cultured according to a modification of the technique of Liu and Karasek (11). The tissue was defatted, then placed in $0.25 \%$ trypsin in $\mathrm{M}-199$ medium at $\mathrm{pH} 7.0$ and trypsinized overnight in air at room temperature. The skin was then rinsed in Dulbecco's modified Eagle's medium (DME) (Basic Cancer Center, Washington University, St. Louis, MO) with $10 \%$ fetal calf serum (KC Biologicals, Inc., Lenexa, KS) and the epidermis was separated from the dermis. Cells were gently shaken from each surface with forceps. The cells were dispersed by trituration and passed through sterile gauze to remove collagen clumps. The epidermal cells were then suspended at a concentration of $1 \times 10^{6} / \mathrm{ml}$ and plated in 16-mm wells (Corning Glass Works, Corning, NY) coated with collagen (Collagen Corp., Palo Alto, CA). The cultures were grown at $37^{\circ} \mathrm{C}$ in $5 \% \mathrm{CO}_{2} / 95 \%$ air. The culture medium was changed every other day. For studies in which $\mathrm{PGE}_{2}$ synthesis and proliferation were measured, serum-containing medium was used to prevent changes in growth secondary to serum deprivation. For studies where exogenous arachidonate was added, serum-free medium was used.

DNA assay and $\left[{ }^{3} H\right]$ thymidine $\left(\left[{ }^{3} H\right] T d r\right)$ incorporation. To measure proliferation, keratinocyte cultures were labeled with $1 \mu \mathrm{Ci} / \mathrm{ml}$ of $\left[{ }^{3} \mathrm{H}\right] \mathrm{Tdr}$ (47 Ci/mmol, Amersham Corp., Arlington Heights, IL) for $12 \mathrm{~h}$. Cultures were then rinsed twice with cold phosphate-buffered saline and harvested by addition of $1 \mathrm{ml}$ of $6 \%$ trichloroacetic acid. After centrifugation, the pellet was resuspended in $200 \mu \mathrm{l} 3 \%$ perchloroacetic acid and heated to $95^{\circ} \mathrm{C}$ for $15 \mathrm{~min}$ to extract DNA. This extract was centrifuged again and $40 \mu \mathrm{l}$ of supernatant was counted to determine thymidine incorporation. A $140-\mu \mathrm{l}$ aliquot was then assayed for DNA content by the diphenylamine method of Burton (12). For cultures plated at $0.25 \times 10^{5} \mathrm{cells} / \mathrm{cm}^{2}$, four 
cultures were pooled for assay. To create triplicate values, 12 wells were plated at this cell density.

Proliferative autoradiography. Cultures intended for autoradiography by the method of Durie and Salmon (13) were grown on thermanox sterile coverslips (Flow Laboratories, Inc., McLean, VA). At the desired time point, cultures were incubated with $1 \mu \mathrm{Ci} / \mathrm{ml}\left[{ }^{3} \mathrm{H}\right] \mathrm{Tdr}$ overnight. The coverslips were then removed from medium and placed cell-sideup into small dishes and fixed. The cultures were then allowed to airdry, after which they were mounted on a clean slide with PRO-TEXX, (Lerner Labs, New Haven, CT) cell-side-up. These slides were then dipped in NTB-2 emulsion (Eastman Kodak Co., Rochester, NY) diluted 1:1 in water in the dark. Once dry, the slides were left to expose at $-78^{\circ} \mathrm{C}$ for $7 \mathrm{~d}$. After the exposure interval, the slides were developed and stained with toluidine blue. When the slides were dry, labeled nuclei per total nuclei present per high power field were counted in a minimum of 20 fields in triplicate slides, yielding a direct visual assay of proliferation.

Analysis of metabolism of $\left[{ }^{14} \mathrm{C}\right]$ arachidonate by cultures. The cultured cells were incubated for $1 \mathrm{~h}$ with $\left[{ }^{14} \mathrm{C}\right]$ arachidonic acid $(0.6 \mu \mathrm{Ci} / \mathrm{ml}, 60.1$ $\mathrm{mCi} / \mathrm{mmol}$, Amersham Corp.) in serum-free medium. Medium from two petri dishes containing $2 \times 10^{6}$ keratinocytes was pooled, acidified to $\mathrm{pH} 3.5$, and extracted three times with an equal volume of ethyl acetate. Samples were evaporated to dryness under nitrogen and resuspended in chloroform/methanol 2:1, plated on silica gel plates, and thin layer chromatography was performed in system A-9 (the organic phase of ethyl acetate/2,2,4-trimethylpentane/acetic acid/ $\mathrm{H}_{2} \mathrm{O}, 55: 25: 10: 50$ ). This system separates prostaglandins and lipoxygenase products. Autoradiograms of the thin layer plates were made with X-OMAT XAR-5 film (Eastman Kodak Co.) and the bands that comigrated with authentic standards were cut from the plates and counted using scintillation spectroscopy (14).

Radioimmunoassay (RIA) of $P G E_{2} . \mathrm{PGE}_{2}$ was assayed using rabbit antisera as previously described (15). The incubations for RIA contained (in a total volume of $0.2 \mathrm{ml}$ ): $\mathrm{PGE}_{2}, 2.0$ to $200 \mathrm{pg} ; 0.05 \mathrm{M}$ potassium phosphate buffer, $\mathrm{pH} 7.4$, containing bovine serum albumin, $0.1 \%$; antiserum in 1:16,000 dilutions; and $\left[{ }^{3} \mathrm{H}\right] \mathrm{PGE}_{2}, 2,500 \mathrm{cpm}(100 \mathrm{Ci} / \mathrm{mmol}$, New England Nuclear, Boston, MA). Tubes were placed in the cold for $18 \mathrm{~h}$ and then dextran-coated charcoal $(0.025 \%$ dextran, $0.15 \%$ charcoal in saline) was added to all tubes, which were centrifuged to pellet the charcoal. The supernatant was then decanted into scintillation fluid (complete counting cocktail 3a70, Research Products International Corp., Mount Prospect, IL) and counted (15).

Protein determination. Cells from all experiments were washed twice with phosphate-buffered saline ( $50 \mathrm{mM}$ potassium phosphate). $0.62 \mathrm{M}$ $\mathrm{NaOH}$ was added to each well to solubilize the protein. The protein concentration in each culture was then determined fluorometrically with fluorescamine (Fluram, Hoffman-La Roche, Inc., Nutley, NJ) using bovine serum albumin as a standard (16).

\section{Results}

Culture morphology. When keratinocyte cultures were plated at $5,2.5,0.75$, or $0.25 \times 10^{5}$ cells $/ \mathrm{cm}^{2}$, marked differences in the culture morphology occurred. Cells plated at the heaviest density $\left(5 \times 10^{5}\right.$ cells) were polygonal with their cytoplasm full of dense, filamentous material. 2-3 cell layers were present by the second day after plating so that the morphology of these cultures resembled normal epidermis. In cultures plated at $2.5 \times 10^{5}$ cells/ $\mathrm{cm}^{2}$, a confluent culture was formed in 1-2 $\mathrm{d}$, but there were only a few areas of stratification. In these areas, the cell cytoplasm contained some dense filamentous material. Experiments were begun shortly after the cultures plated at this density became confluent.

Nonconfluent cultures resulted when cells were plated at a density of $0.75 \times 10^{5}$ cells $/ \mathrm{cm}^{2}$. These cultures contained epithelial islands, with small central areas of stratified cells. In some areas, the islands of epithelium coalesced. Occasionally, cytoplasmic filamentous material was present in the central area of large islands. At the lowest plating density, the morphology was similar, but with the islands of cells more widely dispersed. No filamentous material could be found in the cytoplasm of cells plated at this low density.

The total protein content of the cultures decreased with the decrease in plating density. Stratified confluent cultures $\left(5 \times 10^{5}\right.$ cells $/ \mathrm{cm}^{2}$ ) contained $518 \pm 77 \mu \mathrm{g}$ protein per $16-\mathrm{mm}$ well, while unstratified confluent cultures contained $331 \pm 66 \mu$ g protein per well. Nonconfluent cultures plated at a density of $0.75 \times 10^{5}$ cells $/ \mathrm{cm}^{2}$ contained $72 \pm 21 \mu \mathrm{g}$ of protein per well, while cultures plated at the lowest density contained $18 \pm 5 \mu \mathrm{g}$ protein per well.

Analysis of metabolism of arachidonate by the cultures. Initial studies were done to identify the profile of arachidonate metabolites synthesized by the cultures. $\left[{ }^{14} \mathrm{C}\right]$ Arachidonic acid was added to the culture medium and incubated with the cultures for $1 \mathrm{~h}$. The culture medium from $4 \times 10^{6}$ cells was then extracted and analyzed by thin layer chromatography. These studies showed that the cyclooxygenase products synthesized by the keratinocyte cultures comigrated with $\mathrm{PGE}_{2}, \mathrm{PGF}_{2 \alpha}, \mathrm{PGD}_{2}$, and 6-keto $F_{1 \alpha}$. Lipoxygenase products were also synthesized, but were not identified.

The effect of confluence on prostaglandin synthesis was studied by plating $2 \times 10^{6}$ cells in either $35-\mathrm{mm}$ petri dishes ( 2 $\times 10^{5}$ cells $\left./ \mathrm{cm}^{2}\right)$ or in $25 \mathrm{~cm}^{2}$ flasks $\left(0.8 \times 10^{5} \mathrm{cells} / \mathrm{cm}^{2}\right)$. The cultures in the $35-\mathrm{mm}$ dishes became confluent in $2 \mathrm{~d}$, while the cells plated in the flasks remained nonconfluent for up to $10 \mathrm{~d}$. After 3-5 d in culture, the profile of arachidonate metabolites synthesized by the cultures was determined (see Fig. 1). All of the products synthesized by confluent cultures were made by nonconfluent cultures $\left(\mathrm{PGE}_{2}, \mathrm{PGF}_{2 \alpha}, \mathrm{PGD}_{2}\right.$, and 6-keto $\left.\mathrm{PGF}_{1 \alpha}\right)$. The quantity of metabolites produced per microgram of protein was approximately the same in the two groups, with the exception of $\mathrm{PGE}_{2}$. This prostaglandin was consistently synthesized in fourfold greater quantities in the nonconfluent cultures.

To quantify the difference in $\mathrm{PGE}_{2}$ synthesis between the two groups, unlabeled arachidonic acid $(1-30 \mu \mathrm{M})$ was incubated with cultures plated at confluent $\left(5 \times 10^{5}\right.$ cells $\left./ \mathrm{cm}^{2}\right)$ or nonconfluent $\left(0.75 \times 10^{5}\right.$ cells $\left./ \mathrm{cm}^{2}\right)$ densities for $2 \mathrm{~h}$. The amount of $\mathrm{PGE}_{2} / \mu \mathrm{g}$ of protein synthesized was then determined by RIA (Fig. 2). The dose of arachidonate that resulted in $50 \%$ of the maximal $\mathrm{PGE}_{2}$ synthesis $\left(\mathrm{EC}_{50}\right)$ was $\sim 2 \mu \mathrm{M}$ for both confluent and nonconfluent cultures. The maximal response in nonconfluent cultures, however, was $\sim 20$-fold greater.

The increased capacity for $\mathrm{PGE}_{2}$ synthesis demonstrated in nonconfluent cultures using exogenous arachidonate was also reflected in the cultures' basal rate of $\mathrm{PGE}_{2}$ synthesis. Decreased plating density resulted in a marked increase in the basal rate of $\mathrm{PGE}_{2}$ accumulation in the medium. 3-5-d-old cultures that were confluent or stratified at the time of the assay produced very little $\mathrm{PGE}_{2}$ over a 24-h incubation period. However, nonconfluent cultures produced 50 times this amount over the same period. $\mathrm{PGE}_{2}$ synthesis was completely inhibited by the addition of indomethacin $24 \mathrm{~h}$ before the start of the assay (Fig. $3 \mathrm{~A}$ ).

Studies of proliferation in confluent and nonconfluent cultures. When proliferation was measured using $\left[{ }^{3} \mathrm{H}\right] \mathrm{Tdr}$ incorporation into DNA, it was found that increased synthesis of $\mathrm{PGE}_{2}$ was associated with increased proliferation. Nonconfluent, unstratified cultures proliferated four times more rapidly than did their 


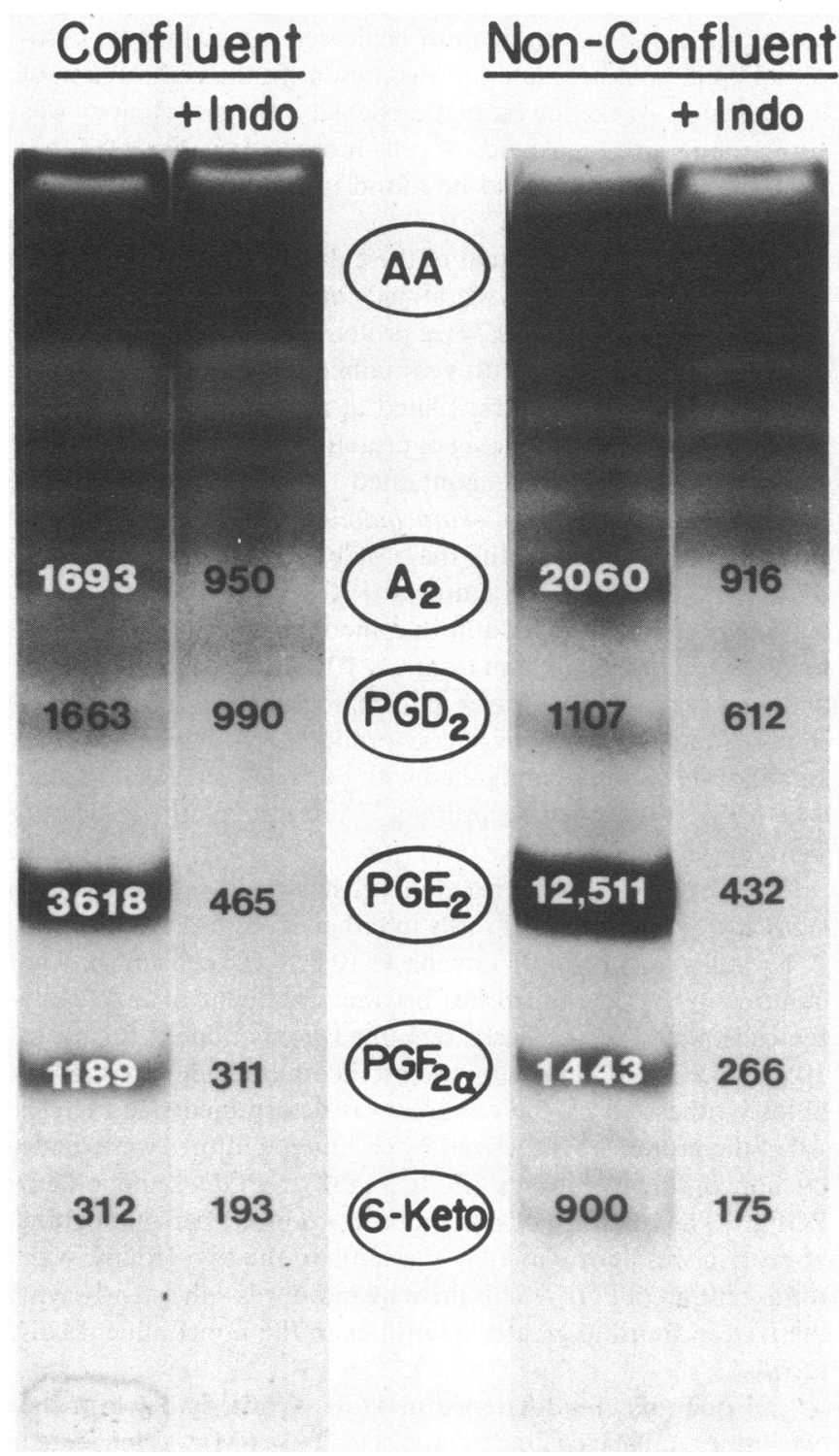

Figure 1. Autoradiogram of thin layer chromatography plate showing products of $\left[{ }^{14} \mathrm{C}\right]$ arachidonic acid formed by $4 \times 10^{6}$ keratinocytes. Incubations were done as described in Methods either in the presence or absence of $5 \mu \mathrm{g} / \mathrm{ml}$ indomethacin (Indo). Chromatographic standards include prostaglandin (PG) 6-keto- $\mathrm{F}_{1 \alpha}, \mathrm{PGF}_{2 \alpha}, \mathrm{PGE}_{2}, \mathrm{PGD}_{2}$, and $\mathrm{PGA}_{2}$. Nonconfluent cultures synthesized four times as much $\mathrm{PGE}_{2} /$ $\mu \mathrm{g}$ protein as confluent cultures. The numbers on the photo show the counts per minute of $\left[{ }^{14} \mathrm{C}\right]$ present in the band indicated. A representative experiment is shown. This experiment was repeated four times with similar results.

fully stratified, confluent counterparts (Fig. $3 \mathrm{~B}$ ). These studies also showed that confluent, unstratified cultures $\left(2.5 \times 10^{5}\right.$ cells/ $\mathrm{cm}^{2}$ ) still proliferate rapidly despite very low levels of $\mathrm{PGE}_{2}$ synthesis. This difference in the cultures' proliferative rate was dependent only on cell density and not on the number of days after plating on which the assay was performed (days 3 through 7).

Since the total counts per minute of $\left[{ }^{3} \mathrm{H}\right] \mathrm{Tdr}$ incorporated into DNA can be influenced by differences in the transport of the radioactive thymidine into the cells, autoradiography was

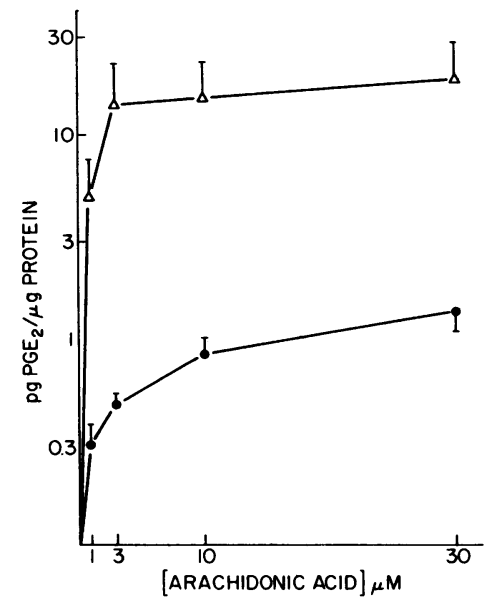

Figure 2. Effect of plating density on exogenous arachidonic acid conversion by keratinocytes. Keratinocytes were plated at $5 \times 10^{5}$ cells/ $\mathrm{cm}^{2}$ (confluent, $\bullet$ ) or 0.75 $\times 10^{5}$ cells $/ \mathrm{cm}^{2}$ (nonconfluent, $\Delta$ ). 3-5-d-old cultures were exposed to $1-30$ $\mu \mathrm{M}$ arachidonic acid for $2 \mathrm{~h}$ and the generated product was assayed by RIA. The values plotted on the graph represent synthesis in addition to basal values. The values shown are the mean \pm SEM, $n=3$.

used as a second method to measure the cultures' rate of proliferation. Using this method, results are obtained by counting the number of cells labeled per total cell number. Since differences in transport will only change the density of labeling, not the number of cells labeled, the results obtained by this method are valid even if differences in radioactive thymidine transport are present. Increases in $\left[{ }^{3} \mathrm{H}\right] \mathrm{Tdr}$ uptake that are due to DNA repair will be visualized as a generalized increase in radioactive background. This is readily distinguished from the intense labeling of mitotic nuclei. The results obtained using proliferative autoradiography confirmed the data obtained by assay of incorporation of $\left[{ }^{3} \mathrm{H}\right] \mathrm{Tdr}$ into DNA (Table I).

To determine if the increase in the rate of proliferation observed in the nonconfluent cultures was modulated by their in-

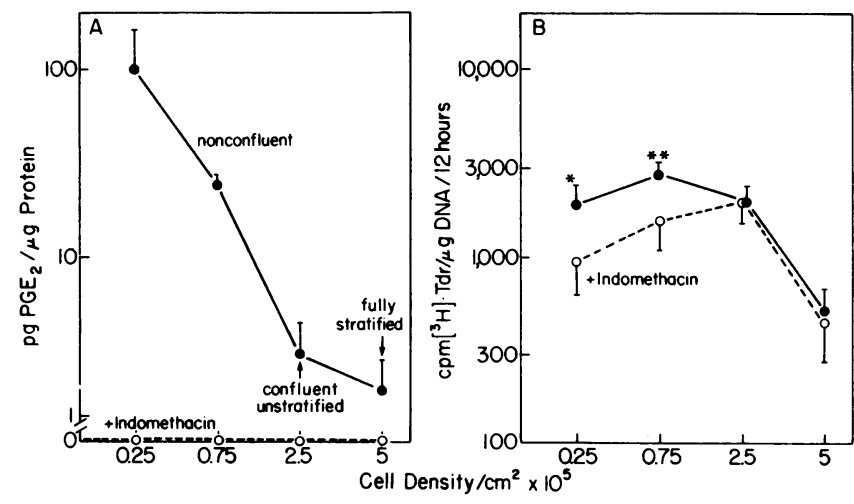

Figure 3. $(A)$ Effect of plating density on $\mathrm{PGE}_{2}$ production. Keratinocytes were incubated with $1 \mathrm{ml}$ DME with $10 \%$ fetal calf serum for 24 h. Cultures plated at $2.5 \times 10^{5}$ cells $/ \mathrm{cm}^{2}$ became confluent $24-48 \mathrm{~h}$ before the assay. Values shown are the mean \pm SEM of six experiments. (B) Effect of plating density on proliferation. Cultures were labeled with $1 \mu \mathrm{Ci} / \mu \mathrm{l}\left[{ }^{3} \mathrm{H}\right]$ thymidine for $12 \mathrm{~h}$ before assay. Cultures that were nonconfluent $\left(0.25 \times 10^{5}\right.$ cells $\left./ \mathrm{cm}^{2}, 0.75 \times 10^{5} \mathrm{cells} / \mathrm{cm}^{2}\right)$ or were unstratified $\left(2.5 \times 10^{5}\right.$ cells $\left./ \mathrm{cm}^{2}\right)$ proliferated four times faster than confluent, stratified cultures ( $(\bullet)$. Cultures exposed to $10 \mu \mathrm{g} / \mathrm{ml}$ indomethacin (O) for $3 \mathrm{~d}$ before $\left[{ }^{3} \mathrm{H}\right] \mathrm{Tdr}$ incorporation determination showed a marked inhibition of proliferation at nonconfluent densities. Values shown are the mean \pm SEM of six experiments. This inhibition of proliferation was statistically significant. ${ }^{*} P<0.02$; ${ }^{* *} P<0.01$, student's paired $t$ test. 
Table I. Effect of Confluence on Keratinocyte Proliferation (cells labeled/100 cells)

\begin{tabular}{|c|c|c|}
\hline \multicolumn{2}{|c|}{ Confluent $\left(2.5 \times 10^{5}\right.$ cells $\left./ \mathrm{cm}^{2}\right)$} & Nonconfluent $\left(0.75 \times 10^{5}\right.$ cells $\left./ \mathrm{cm}^{2}\right)$ \\
\hline & $\begin{array}{l}+10 \mu \mathrm{g} / \mu \mathrm{l} \\
\text { indomethacin }\end{array}$ & $\begin{array}{l}+10 \mu \mathrm{g} / \mathrm{ml} \\
\text { indomethacin }\end{array}$ \\
\hline $2.8 \pm 0.5$ & $2.6 \pm 0.5$ & $5.2 \pm 0.7$ \\
\hline
\end{tabular}

Keratinocytes were plated at confluent or nonconfluent densities. $2 \mathrm{~d}$ after plating, half of the cultures were treated with $10 \mu \mathrm{g} / \mathrm{ml}$ indomethacin. After $3 \mathrm{~d}$ of drug treatment, the cultures were processed for proliferative autoradiography. The numbers represent the number of cells labeled per 100 cells \pm SEM in each treatment group. $n=3$.

creased rate of $\mathrm{PGE}_{2}$ synthesis, the cultures were treated with indomethacin for $3 \mathrm{~d}$. $\mathrm{PGE}_{2}$ synthesis was completely inhibited at concentrations of indomethacin as low as $0.1 \mathrm{mg} / \mathrm{ml}$. The rate of proliferation of indomethacin-treated cultures was then assayed. It was found that in nonconfluent cultures only, the rate of proliferation was decreased $35-45 \%$ in the presence of the drug (Figs. $3 A$ and 4).

At each concentration of indomethacin that suppressed $\mathrm{PGE}_{2}$ synthesis, proliferation was inhibited. At a concentration of 0.01 $\mu \mathrm{g} / \mathrm{ml}$ indomethacin, however, $\mathrm{PGE}_{2}$ synthesis was not fully suppressed. In these cultures, the rate of proliferation was the same as controls. This decrease in proliferation was also confirmed by proliferative autoradiography (see Table I). The rate of proliferation of confluent cultures (stratified or unstratified) was unchanged by indomethacin treatment (Fig. $3 \mathrm{~B}$ ).

To document that $\mathrm{PGE}_{2}$ was the product of the cyclooxygenase pathway that was responsible for the increased proliferative rate observed in nonconfluent cultures, exogenous $\mathrm{PGE}_{2}$, $\mathrm{PGF}_{2 \alpha}, \mathrm{PGD}_{2}$, and the stable $\mathrm{PGI}_{2}$ analog ONO-OP4193 were added to indomethacin-treated cultures and the effect on their rate of proliferation was assessed after $3 \mathrm{~d}$. Cultures were plated at a density of either $5 \times 10^{5}$ cells $/ \mathrm{cm}^{2}$ (fully confluent and stratified) or at 0.75 cells $/ \mathrm{cm}^{2}$ (nonconfluent). The concentration
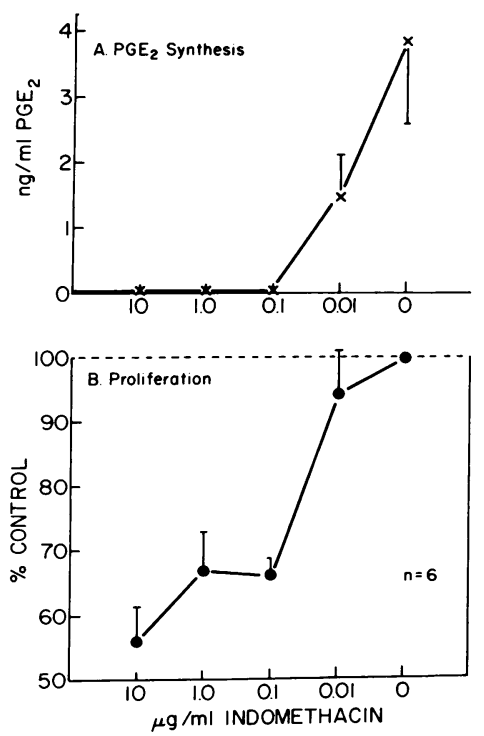

Figure 4. Effect of indomethacin treatment on nonconfluent keratinocyte proliferation. Cultures $\mathbf{0} 0.75$ $\times 10^{5} / \mathrm{cm}^{2}$ ) were exposed to $10,1,0.1$, or $0.01 \mu \mathrm{g} / \mathrm{ml}$ indomethacin for $3 \mathrm{~d}$. The $\mathrm{PGE}_{2}$ synthesis during the $24 \mathrm{~h}$ before harvest and the rate of proliferation were then determined. Inhibition of proliferation occurred at all doses of indomethacin in which prostaglandin synthesis was suppressed, $P$ $<0.005$, student's paired $t$ test. In the presence of 0.01 $\mu \mathrm{g} / \mathrm{ml}$ indomethacin, prostaglandin metabolism was not suppressed, and the cultures proliferated at the same rate as controls.

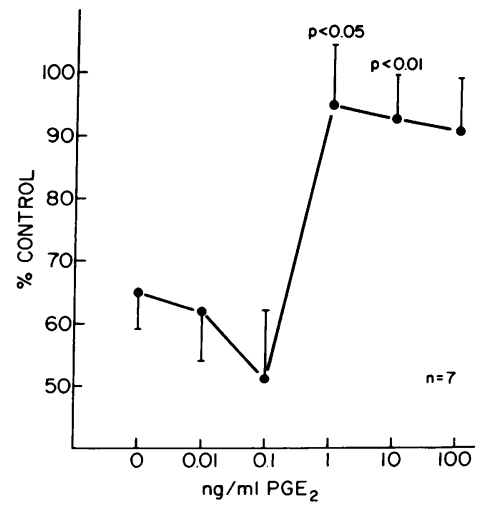

Figure 5. Reconstitution of the normal proliferative rate of nonconfluent cultures $\left(0.75 \times 10^{5} / \mathrm{cm}^{2}\right)$ with $\mathrm{PGE}_{2}$ in the presence of indomethacin, $1 \mu \mathrm{g} / \mathrm{ml}$. Addition of $\mathrm{PGF}_{2 \alpha}, \mathrm{PGD}_{2}$, or Ono OP-4193 (a stable analogue of $\mathrm{PGI}_{2}$ ) did not increase the cultures' rate of proliferation above the value measured in indomethacin-treated cultures. Values shown represent the mean \pm SEM. Reconstituted values are statistically different from indomethacin treated controls, student's paired $t$ test.

of prostaglandin added to the cultures $(0.01$ to $100 \mathrm{ng} / \mathrm{ml})$ was in the physiologic range of the products synthesized by keratinocytes in a 24-h period. These experiments showed that addition of $\mathrm{PGE}_{2}$ to the cultures resulted in reconstitution of their normal rate of proliferation as measured by incorporation of $\left[{ }^{3} \mathrm{H}\right] \mathrm{Tdr}$ into DNA (Fig. 5). This response was dose-dependent, with the proliferative rate reconstituted to the control value at a dose of $1 \mathrm{ng} / \mathrm{ml} \mathrm{PGE}_{2}$. In sharp contrast, the cultures' proliferative rate in the presence of up to $100 \mathrm{ng} / \mathrm{ml}$ of the other prostaglandins that keratinocytes synthesize was the same as the indomethacin control.

\section{Discussion}

These data indicate that keratinocyte $\mathrm{PGE}_{2}$ synthesis is modulated by cell density, and that $\mathrm{PGE}_{2}$ is a growth promoting autocoid in nonconfluent keratinocyte cultures. The increase in endogenous $\mathrm{PGE}_{2}$ accumulation observed in the nonconfluent keratinocyte cultures was apparently mediated by an increase in cyclooxygenase activity, as suggested by the studies using exogenous arachidonate (Fig. 2). These studies indicated that the $\mathrm{EC}_{50}$ for both confluent and nonconfluent cultures is approximately the same, but that the quantity of product which can be synthesized in nonconfluent cultures is increased 20 -fold. The apparent preferential synthesis of $\mathrm{PGE}_{2}$ over $\mathrm{PGF}_{2 \alpha}, \mathrm{PGD}_{2}$, and 6-keto $\mathrm{PGF}_{1 \alpha}$ may be the result of increased $\mathrm{PGH}_{2}-\mathrm{PGE}_{2}$ isomerase activity or relative decreases in the enzymes synthesizing $\mathrm{PGF}_{2 \alpha}, \mathrm{PGD}_{2}$, and $\mathrm{PGI}_{2}$. The mechanism by which keratinocytes preferentially synthesize $\mathrm{PGE}_{2}$ is not addressed in these studies.

The relationship of the increase in prostaglandin synthesis to the state of confluence of the keratinocyte culture was supported by several observations. The quantity of prostaglandin synthesized was not influenced by the number of days the cells were in culture, only by their degree of confluence. When the same number of cells were plated in different sized petri dishes, resulting in confluent or nonconfluent cultures, synthesis was increased fourfold in the nonconfluent cultures. These studies do not address whether confluence, the cessation of cell spreading, or differentiation of the keratinocyte cultures is responsible for the observed decrease in prostaglandin synthesis as plating density increases. 
In the studies in which keratinocyte proliferation was measured (Fig. 3), it was shown that the increased synthesis of $\mathrm{PGE}_{2}$ by nonconfluent keratinocyte cultures enhances their rate of proliferation. It was also demonstrated that once these cultures are confluent, prostaglandin synthesis no longer facilitates proliferation, which suggests that keratinocytes are able to proliferate by both a prostaglandin-dependent and prostaglandin-independent pathway. Also note that confluent, unstratified cultures proliferate as fast as nonconfluent cultures but synthesize much less $\mathrm{PGE}_{2}$, which indicates that while confluence modulates $\mathrm{PGE}_{2}$ synthesis, it does not directly modulate proliferation. Confluent cultures continue to proliferate rapidly until they are stratified, despite very low levels of $\mathrm{PGE}_{2}$ synthesis. These results may explain the great diversity of effects reported in the literature when the relationship between keratinocyte proliferation and arachidonic acid metabolism has been studied. The dependence of proliferation on prostaglandin synthesis only under certain experimental conditions has been encountered in in vivo studies. Marks et al. (2) showed that while TPA-induced hyperproliferation was dependent upon $\mathrm{PGE}_{2}$ synthesis, the hyperproliferation produced by its close analogue, 4- $\mathrm{O}$-methyl-TPA, was not.

The decreases in arachidonate metabolism and proliferation, which occur as keratinocytes become confluent and differentiate, is different from the pattern of events observed in other cell types. Taylor and Polgar (17) showed that in quiescent fibroblast cultures (nonproliferative) bradykinin-stimulated synthesis of $\mathrm{PGE}_{2}$ is greatly enhanced (17). Friend erythroleukemia cells and the human promyelocytic cell line HL 60 have been observed to have increased cyclooxygenase and phospholipase activity after differentiation was induced with dimethyl sulfoxide $(18,19)$. These examples indicate that in many cell types, increased $\mathrm{PGE}_{2}$ synthesis occurs with increased differentiation and decreased proliferation. Keratinocytes, however, are able to enhance the rate of proliferation of undifferentiated cells through increased $\mathrm{PGE}_{2}$ synthesis.

In quiescent Swiss 3T3 fibroblast cultures, DeAsua et al. (20) have shown that another prostaglandin, $\mathrm{PGF}_{2 \alpha}$, can function as a growth factor. Exogenous addition of $75 \mathrm{ng} / \mathrm{ml} \mathrm{PGF} \mathrm{PF}_{2 \alpha}$ can initiate DNA synthesis. Physiologic quantities of $\mathrm{PGF}_{2 \alpha}$ can also initiate synthesis in the presence of $\mathrm{PGE}_{2}$ and insulin (21). A similar role for $\mathrm{PGE}_{2}$ in keratinocyte proliferation is demonstrated by the present studies.

In a recent report by Rice and Levine (22) using keratinocytes cultured from a squamous cell carcinoma, the cultures' synthesis of prostaglandins in response to mellitin was shown to decrease as the cultures became confluent and presumably proliferated more slowly (22). Our studies confirm these findings in normal cells, and in addition, document the relationship between the culture's rate of proliferation and its prostaglandin synthesis.

In studies of EFAD rats with burn or incisional injuries (7), epithelial repair is markedly delayed, with regeneration requiring three times longer than normal to occur. Since the skin of EFAD animals does not contain the precursor essential fatty acids for $\mathrm{PGE}_{2}$ synthesis (10), this increase in repair time may represent the in vivo correlate of the findings reported here. In vitro, nonconfluent keratinocyte cultures may behave similarly to the regenerating islands of epithelium, which appear after partial thickness injury. In an EFAD animal, the absence of $\mathrm{PGE}_{2}$ may slow the rate at which these nonconfluent islands of epithelium become confluent. The study of nonconfluent keratinocyte cultures' arachidonic acid metabolism as a model of wound healing may give insight into the process of epithelial repair. An abnormality in the epithelial ability to augment $\mathrm{PGE}_{2}$ synthesis after injury may also be of importance in hyperproliferative inflammatory disease states such as psoriasis, where increased arachidonic acid metabolism and increased epithelial proliferation are present (21).

\section{Acknowledgments}

We would like to thank Dr. Seltzer and Dr. Eisen for supplying the human skin.

This work was supported in part by grants from Johnson and Johnson Co. through the Dermatology Foundation, the Pediatric Dermatology Society, and National Institutes of Health grant 5-R01-HL20787.

\section{References}

1. Ashendel, C. L., and R. K. Boutwell. 1979. Prostaglandin E and $F$ levels in mouse epidermis are increased by tumor-promoting phorbol esters. Biochem. Biophys. Res. Commun. 90:623-627.

2. Furstenberger, G., M. deBravo, S. Bertsch, and F. Marks. 1979. The effect of indomethacin on cell proliferation induced by chemical and mechanical means in mouse epidermis in vivo. Res. Commun. Chem. Pathol. Pharmacol. 24:533-541.

3. Furstenberger, G., and F. Marks. 1978. Indomethacin inhibition of cell proliferation induced by the phorbolester TPA is reversed by prostaglandin $\mathrm{E}_{2}$ in mouse epidermis in vivo. Biochem. Biophys. Res. Commun. 84:1103-1111.

4. Bentley-Phillips, C. B., H. Paulli-Jørgensen, and R. Marks. 1977. The effects of prsotaglandins $\mathrm{E}_{1}$ and $\mathrm{F}_{2 \alpha}$ on epidermal growth. Arch. Dermatol. Res. 257:233-237.

5. Lowe, N. J., and R. B. Stoughton. 1977. Effects of topical prostaglandin $E_{2}$ analogue on normal hairless mouse epidermal DNA synthesis. J. Invest. Dermatol. 68:134-137.

6. Bem, J. L., and M. W. Greaves. 1974. Prostaglandin $E_{1}$ effects on epidermal cell growth "in vitro." Arch. Dermatol. Forsch. 251:35-41.

7. Hulsey, T. K., J. A. O'Neill, W. R. Neblett, and H. C. Meng. 1980. Experimental wound healing in essential fatty acid deficiency. J. Pediatr. Surg. 15:505-508.

8. Harper, R. A. 1976. Effect of prostaglandins on [ $\left.{ }^{3} \mathrm{H}\right]$-thymidine uptake into human epidermal cells in vitro. Prostaglandins. 12:10191025.

9. McCullough, J. L., S. H. Schreiber, and V. A. Ziboh. 1978. Cell proliferation kinetics of epidermis in the essential fatty acid deficient rat. J. Invest. Dermatol. 70:318-320.

10. Ziboh, V. A., and S. L. Hsia. 1972. Effects of prostaglandin $E_{2}$ on rat skin: inhibition of sterol ester biosynthesis and clearing of scaly lesions in essential fatty acid deficiency. J. Lipid Res. 13:458-467.

11. Liu, S. C., and M. Karasek. 1978. Isolation and growth of adult human epidermal keratinocytes in cell cultures. J. Invest. Dermatol. 71: 157-162.

12. Burton, K. 1968. Determination of DNA concentration with diphenylamine. Methods Enzymol. 12:163-166.

13. Durie, B. G. M., and S. E. Salmon. 1975. High speed scintillation autoradiography. Science (Wash. DC). 190:1093-1095.

14. Sheng, W. Y., T. A. Lysz, A. Wyche, and P. Needleman. 1983. Kinetic comparison and regulation of the cascade of microsomal enzymes involved in renal arachidonate and endoperoxide metabolism. J. Biol. Chem. 258:2188-2192.

15. Reingold, D. F., K. Watters, S. Holmberg, and P. Needleman. 1981. Differential biosynthesis of prostaglandins by hydronephrotic rabbit and cat kidneys. J. Pharmacol. Exp. Ther. 216:510-515.

16. Udenfriend, S., S. Stein, P. Böhlen, W. Dairman, W. Leimgruber, 
and M. Weigele. 1972. Applications of fluorescamine, a new reagent for assay of amino acids, peptides and other primary amines in the picomole range. Science (Wash. DC). 178:871-872.

17. Taylor L., and P. Polgar. 1981. Cell growth and the regulation of prostaglandin synthesis. Prostaglandins. 22:723-728.

18. Santoro, M. G., and B. M. Jaffe. 1982. Role of prostaglandins on the growth and differentiation of friend erythroleukemia cells. In Prostaglandins and Cancer: First International Conference. T. J. Powles, R. S. Bockman, K. V. Honn, and P. Ramwell, editors. Alan R. Liss, Inc. New York. 425-436.

19. Bonser, R. W., M. I. Siegel, R. T. McConnell, and P. Cuatrecasas. 1981. The appearance of phospholipase and cyclooxygenase activities in the human promyelocytic leukemia cell line HL-60 during dimethyl sulfoxide-induced differentiation. Biochem. Biophys. Res. Commun. 98: 614-620.
20. DeAsua, L. J., D. Clingan, and P. S. Rudland. 1975. Initiation of cell proliferation in cultured mouse fibroblasts by prostaglandin $\mathrm{F}_{2 \alpha}$. Proc. Natl. Acad. Sci. USA. 72:2724-2728.

21. Otto, A. M., M. Nilsen-Hamilton, B. D. Boss, M. O. Ulrich, and L. H. DeAsua. 1982. Prostaglandins $E_{1}$ and $E_{2}$ interact with prostaglandin $F_{2 \alpha}$ to regulate initiation of DNA replication and cell division in Swiss 3T3 cells. Proc. Natl. Acad. Sci. USA. 79:4992-4996.

22. Rice, R. H., and L. Levine. 1984. Mellitin-stimulated arachidonic acid metabolism by cultured malignant human epidermal keratinocytes. Biochem. Biophys. Res. Commun. 124:303-307.

23. Hammarstrom, S., M. Hamberg, B. Samuelsson, E. A. Duell, M. Stawiski, and J. J. Voorhees. 1975. Increased concentrations of nonesterified arachidonic acid, 12L-hydroxy-5,8,10,14-eicosatetraenoic acid, prostaglandin $\mathrm{E}_{2}$, and prostaglandin $\mathrm{F}_{2 \alpha}$ in epidermis of psoriasis. Proc. Natl. Acad. Sci. USA. 72:5130-5134. 